\title{
Applying research for enhanced productivity on the Canadian Ecology Centre - Forestry Research Partnership forests
}

\author{
by Scott McPherson ${ }^{1}, 2$, F. Wayne Bell ${ }^{3}$, Jeff Leach ${ }^{4}$, Peter Street ${ }^{5}$ and Al Stinson ${ }^{1}$
}

\begin{abstract}
The application of enhanced forest productivity (EFP) through intensive silviculture on designated forest areas is arguably one means to maintain or increase fibre supply and global market competitiveness. The Canadian Ecology Centre Forestry Research Partnership's (CEC-FRP) 10/10 objective (to increase sustainable fibre production by $10 \%$ in 10 years) has focused many years of forest research largely on the practical application of EFP. Large-scale implementation of this research, through a process of adaptive management, is incumbent on first identifying forests that are available and potentially suitable to implement EFP with more intensive silviculture on portions of the landbase. This paper describes forests in northeastern Ontario that were evaluated for EFP potential, and provides some of the rationale for their selection or rejection for this purpose. To date, the Gordon Cosens, Romeo Malette, Martel, and Nipissing forests are identified as potential CEC-FRP core forests in which research can be directed towards sustainable increases in forest production. These 4 forests are located in Ontario's boreal and Great Lakes-St. Lawrence regions and have the necessary tenure, potential productivity, protection from fire, insect and disease, and are managed under a suitably enabling planning and legislative environment. In addition, forest management planning teams for these forests are closely integrated with the CECFRP through core teams that are critical to identifying science priorities based on local operational issues, and moving subsequent research into practice. As such, it seems timely to move forward with EFP implementation through a process of adaptive management on these forests.
\end{abstract}

Key words: enhanced forest productivity (EFP), intensive forest management (IFM), intensive silviculture, forest management planning (FMP), adaptive management

\section{RÉSUMÉ}

Lobtention d'une productivité forestière accrue (PFA) au moyen de la sylviculture intensive sur des territoires forestiers désignés constitue sans doute l'un des moyens permettant de maintenir ou d’accroître l'approvisionnement en fibre et la compétitivité sur les marchés mondiaux. L’objectif 10/10 (accroître la production durable de fibre de $10 \%$ en 10 ans) du Centre écologique du Canada - Partenariat pour la recherche forestière (CEC-PRF) a consacré plusieurs années de recherche forestière principalement sur l'application pratique de la PFA. Limplantation à grande échelle de ces recherches, par l'entremise d'un processus d’adaptation de l'aménagement, dépend en premier lieu de l'identification des forêts qui sont disponibles et potentiellement en mesure de suivre une PFA générée par une sylviculture intensive sur des portions du territoire. Cet article décrit les forêts du nord-est de l'Ontario qui ont été évaluées pour leur potentiel de PFA et présente quelques-uns des éléments rationnels de leur sélection ou de leur rejet en fonction de cet objectif. À ce jour, les forêts Gordon Cosens, Romeo Malette, Martel et Nipissing ont été retenues en tant que principaux éléments ayant la possibilité d’atteindre lobjectif du CEC-PRF et sur lesquelles les recherches peuvent être dirigées pour lobtention daccroissements soutenus de production forestière. Ces 4 forêts sont situées dans les régions de la forêt boréale et des Grands Lacs St-Laurent de l'Ontario et présentent une tenure adéquate, une productivité potentielle, une protection contre les feux de forêt, les insectes et les maladies et sont aménagées selon une planification idéalement obligeante et sous un environnement législatif adapté. De plus, les équipes chargées de la planification de laménagement forestier de ces forêts sont étroitement liées au CEC-PRF par l'entremise d'un groupe central qui joue un rôle essentiel dans l'identification les priorités scientifiques basées sur les questions opérationnelles locales et dans l'utilisation des recherches sur le terrain. Somme toute, il est maintenant possible d'effectuer l'implantation de la PFA au moyen d'un processus d'adaptation de l'aménagement de ces forêts.

Mots clés : productivité forestière accrue (PFA), aménagement forestier intensif (AFI), sylviculture intensive, planification de l’aménagement forestier (PAF), adaptation de l’aménagement

\footnotetext{
${ }^{1}$ Ontario Ministry of Natural Resources, Southern Science and Information Section, 3301 Trout Lake Road, North Bay, Ontario, P1A 4L7.

${ }^{2}$ Corresponding author. E-mail: scott.mcpherson@ontario.ca

${ }^{3}$ Ontario Ministry of Natural Resources, Ontario Forest Research Institute, 1235 Queen Street, Sault Ste. Marie, Ontario, P6A 2 E5.

${ }^{4}$ Tembec, PO Box 100, Kapuskasing, Ontario, P5N 2 Y2.

${ }^{5}$ Nipissing Forest Resource Management, Inc, 128 Lansdowne Ave. East, Callander, Ontario, P0H 1H0.
} 


\section{Introduction}

Discussions about the intensity at which forests should be managed are ongoing. It is argued that intensive forest management is necessary in parts of the worlds' forests to help mitigate fibre supply shortages, maintain or increase competitiveness in global forest sectors, and continue or increase protection of natural areas, i.e., to grow more fibre on less land (Sedjo 2001, Wagner 2005). It is also argued that intensification may, or may not, be appropriate for designated areas of Canada's northern forests (e.g., Lautenschlager 2000, Messier et al 2003, Carmean 2007, Park and Wilson 2007). The question is: Are higher-yielding forestry practices realistic given the environmental, regulatory, social, and economic constraints commonly faced in Canada, particularly on Crown land where much of the nation's forests occur? More specifically, will intensive management be effective in the forests of the southern boreal and northern Great Lakes-St. Lawrence (GLSL) regions of Ontario where much of the debate is centred? At present, most Crown forests in Ontario are managed under basic or extensive regimes (Bell et al. 2006), but the feasibility of more intensive management may be achieved, or at least tested, through a process of adaptive management. A recent desire to do so stems in part from the Ontario Forest Accord, which suggests that reductions in commercial forest following the creation of new parks and protected areas may be partially offset by more enhanced forest productivity (EFP).

The Ontario Forest Accord is a three-way agreement between the forest industry, conservation organizations and the Government of Ontario that moves forward on a process to complete a scientifically sound protected areas system and establish a more secure environment for industry (OFAAB 2001). This agreement set bounds on the use of intensive practices (OFAAB 2001, 2002). These were that:

- Any effect on existing wood supplies for mills created by the establishment of new parks and reserves would be mitigated by measures such as wood trading between mills, changes to the stumpage (royalty) system to encourage restoration and improvement cuts, stand thinning to increase growth rates, and harvesting of small-diameter wood.

- There would be no negative effect to long-term delivered wood costs and volumes.

- The value of intensive forest management (IFM) as a way of enhancing productivity would be assessed, because much uncertainty remains about its effectiveness and effects.

- Any volume of wood available above and beyond a $10 \%$ threshold over the volume of wood used by mills across Ontario as of March 1999 (when the Accord came into force), would be shared between allocations to new parks and reserves and for industrial use through the Room to Grow process.

- Incentives for IFM were to focus on research partnerships between government and industry to investigate the effectiveness and effects of intensive practices (excluding fertilization, drainage and use of genetically modified organisms).

- All environmental protection guidelines would continue to apply in all areas including designated enhanced woody supply areas (EWSAs) where more intensive silviculture would be targeted.
As well, this agreement led to the initiation of the Canadian Ecology Centre - Forestry Research Partnership (CECFRP; Bruemmer 2008, this issue). Since the signing of the Accord, the CEC-FRP has investigated opportunities to enhance forest productivity and yields in Ontario. The goal of the CEC-FRP is to increase sustainable fibre production by $10 \%$ in 10 years (the 10/10 objective) on Tembec's licensed areas (Bruemmer 2008, this issue). In part, this goal may be achieved with a shift to more enhanced forest productivity (EFP) i.e., the application of more intensive practices on a suitable portion of managed forests. The CEC-FRP proposes using an active adaptive management approach (Bell et al. $2008 \mathrm{a}$, this issue) to test the feasibility of EFP on portions of the managed forest landbase.

The objectives of this paper are to provide an overview of Ontario's forest management planning process in relation to the potential for intensification, and to describe the forests being considered for testing of EFP implementation through initiatives of the CEC-FRP. We also present some of the potential opportunities and challenges of implementing EFP, and explore the suitability of the northeast region of Ontario.

\section{Forest Management in Ontario}

Ontario's forest covers over 70 million hectares ( $\mathrm{M} \mathrm{ha}$ ), of which over $80 \%$ is owned by the Crown. Within the Area of the Undertaking (AOU) where commercial forest management is permitted on Crown land, 32.7 $\mathrm{M}$ ha are productive forest. Of this, $18.8 \mathrm{M}$ ha, or $17.5 \%$ of Ontario's total area, make up the net operable commercial Crown forests (OMNR 2006). The AOU is divided into forest management units, all but 2 of which are currently tenured under Sustainable Forest Licences (SFLs). This tenure system provides forest industries with harvest rights for up to 20 years through licence holders, along with the responsibilities for renewal and other silvicultural activities. The Ontario Ministry of Natural Resources (OMNR) retains accountability to the public for the management of the Crown resources and responsibilities for protection and the right to renew licenses following satisfactory independent forest audits (Euler and Epp 2000).

Each SFL requires that comprehensive forest management plans spanning 20-year periods be prepared for each management unit every 10 years (OMNR 2004a). Forest management plans are developed by teams comprising industry, government, First Nations, non-government organizations, and public representation, and must be approved by OMNR. The public is represented primarily through local citizens committees (LCC). Collectively, the planning team sets the longterm management direction for the planning area (OMNR 2004a). The inclusiveness of this planning framework fits well with integrating the CEC-FRP core teams into the planning process (Smith et al. 2008, this issue). The core teams consist of Tembec and SFL staff, OMNR staff from district, regional, and science offices, and CEC-FRP representatives. Each member is responsible for different aspects of forest operations, strategic planning, research, and technology transfer. For partnership forests, the core teams provide a direct conduit between forest management planning and CEC-FRP research through the identification of local issues, and development of science solutions. This allows for direct input of research into practice and enables implementation of an adaptive management approach on partnership forests. 


\section{The Forests}

One of the first steps towards the CEC-FRP's 10/10 objective was to identify forests in Ontario that are available and potentially suitable for EFP. Availability depends on access to fibre (tenure) and an enabling regulatory and planning framework, as well as some assurance of both an immediate increase in wood supply through an allowable cut effect (ACE; Luckert and Haley 1995) and longer-term increases. Although economic returns are questionable (Hegan and Luckert 2000), and Ontario's forest managers have concerns about future tenure security, interest in investing in more intensive silviculture exists given that it may mitigate anticipated fibre shortfalls (OMNR 2004b). In situations where fibre supply is constrained, EFP becomes a logical option to augment supply, although there are trade-offs between harvest flow and financial benefits (Mathey et al. 2008).

The suitability of Ontario's forests for EFP depends on accessibility of wood supply, inherent site productivity, and some assurance of protection from fire, insect, and disease. Areas not available for EFP due to known and probable policy and regulatory conflicts must also be identified. The current forest policy and planning framework in Ontario (e.g., OFAAB 2002, OMNR 2004b), however, can accommodate intensive management practices as defined in Bell et al. (2008b, this issue). Industrial demand for fibre is also an important consideration, i.e., EFP is only worthwhile where there is consistent pressure to maintain or increase wood supply. These aspects are explored for selected management units in the province's northeast region (Fig. 1).

There are 46 forest management units in Ontario, some of which are directly affiliated with the CEC-FRP through Tembec. Tembec manages the Gordon Cosens, Martel, Smooth Rock Falls, Cochrane-Moose River, and Romeo Malette forests. In addition, Tembec has wood supply commitments from many other forests and therefore has an active role in forest management planning and operations. Of these forests, the CEC-FRP has been particularly active on the Nipissing Forest, which surrounds the Canadian Ecology Centre, near Mattawa.

Collectively, these forests provide an opportunity to implement EFP directed research on a large scale. Several factors make this landscape appealing for EFP:

1. Its diversity- potential for EFP varies with the noticeable environmental gradient from north to south (i.e., cold with poor drainage in the north to milder and more productive with higher species diversity to south; Thompson 2000). As such, certain areas are inherently better suited for intensive silviculture, while others may be managed more extensively to meet other objectives.

2. A common mechanism for protection against fire, insects, and disease-the OMNR has the responsibility for fire control and has implemented a fire management strategy that enables protection of high value areas (e.g., communities, cottage areas, plantations) using aggressive fire control while allowing natural fire regimes to occur in specified areas with less economic values (e.g., remote, un-accessed areas) (OMNR 2004c, Martell and Sun 2008). Insect control and mitigation of disease and catastrophic weather events is covered by designated funds (Forest Futures Trust), allowing for the protection and possible restoration of high-value plantations and wood supply areas at the request of forest managers.

3. Available wood supply and ability to integrate EFP with other forest values-the size of these SFLs is likely appropriate to accommodate a meaningful level of EFP on a conservative portion of their landbase, while still allowing for protected areas (Fig. 2) and for much of the forest area to be managed less intensively. Analysis of the spatial feasibility of IFM that was done in 2001 for the Gordon Cosens, Romeo Malette, and Nipissing forests, and subsequent spatial modelling with Patchworks (e.g., Rouillard and Moore 2008, this issue) has identified substantial areas where IFM is not limited by existing or probable regulatory and guide restrictions (i.e., areas of concern, buffer zones, wildlife habitat constraints).

Here we briefly describe 6 partnership forests that are linked to the CEC-FRP through licence agreements with Tembec and core teams. The forests are described, from north to south, in relation to their potential for EFP implementation.

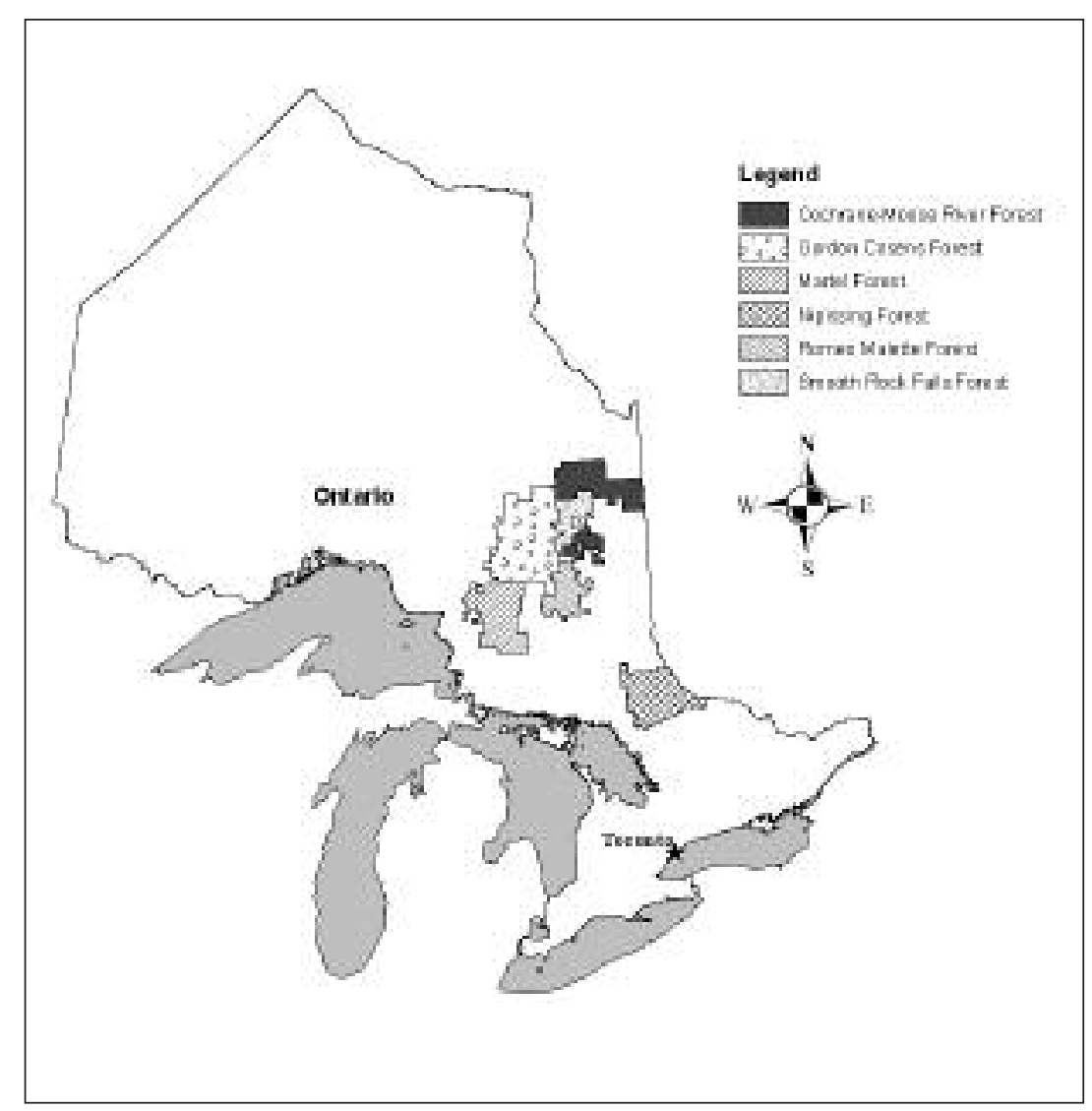

Fig. 1. Location of forest management units currently linked to core teams of the Canadian Ecology Centre - Forestry Research Partnership in Ontario, Canada. 


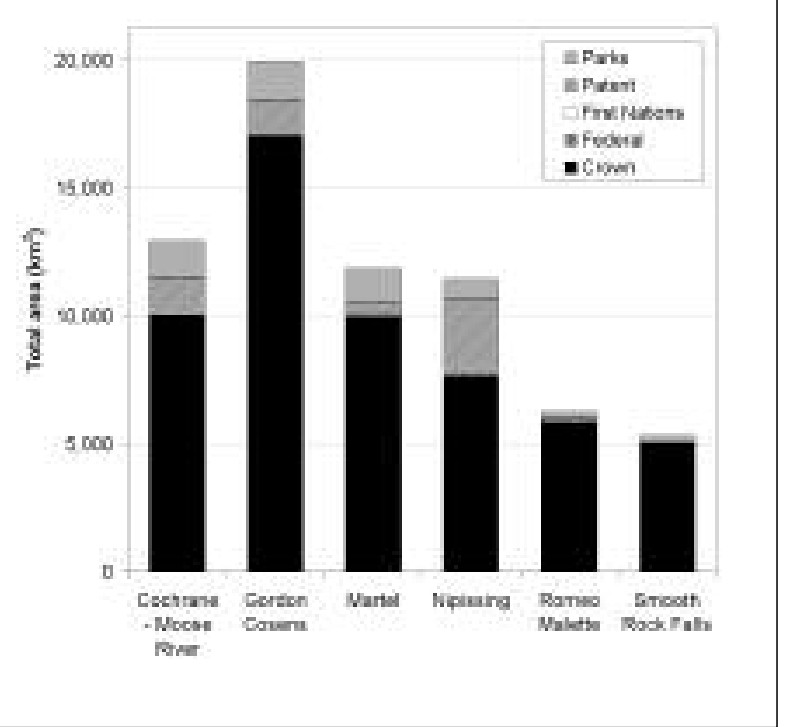

Fig. 2. Total management unit area by ownership for Canadian Ecology Centre - Forestry Research Partnership forests.

\section{Cochrane-Moose River Forest}

The Cochrane-Moose River Forest (CMRF) is situated around the town of Cochrane, Ontario, and along the northern boundary of the province's forest management units. There are two distinct portions of the forest, separated by the Smooth Rock Falls and Iroquois Falls Forests (Fig. 1). Presently, the CMRF is one of the two remaining Crown management units in the province, although it is being considered for amalgamation with neighbouring SFLs.

The CMRF lies in the heart of the Clay Belt that spans about $125000 \mathrm{~km}^{2}$, mainly above the $49^{\text {th }}$ parallel across the Ontario-Quebec border (Lavoie et al. 2005). Large expanses of clay were deposited here by the glacial lakes Barlow and Ojibway, and much of this was subsequently overtopped with till during re-advances of the ice sheet (MacLean and Bedell 1955, Armson 2001, Lavoie et al. 2005). Because of the lowlying topography and poor drainage, wet soils and peatlands dominate the Clay Belt (Lavoie et al. 2005). As a result, sparsely treed and open bogs are common within the CMRF: classified satellite data shows almost $3000 \mathrm{~km}^{2}$ (23\% of total management unit area) as bog, swamp, or fen (Fig. 3). The poor drainage and shortage of gravel for road construction and maintenance make access for harvesting and silviculture difficult and expensive. Consequently, access is often restricted to "winter roads" and frozen ground, neither of which is conducive to subsequent silvicultural treatments.

Lowland conifer forests comprising black spruce (Picea mariana [Mill.] BSP), eastern white cedar (Thuja occidentalis L.), and tamarack (Larix laricina [Du Roi] K. Koch) predominate (Table 1), which has changed to some extent since industrial harvesting began. A reconstruction of pre-industrial forest composition was done from Ontario Crown land survey notes for the CMRF for the 1898 to 1931 period using the method and data described in Pinto et al. (2008). Comparison with current forest inventory data along the same surveyed township boundaries indicates balsam fir (Abies bal- samea [L.] Mill.), poplar (Populus) and spruce (Picea) occur more frequently, while birch (Betula) and tamarack occur less frequently (F. Pinto, OMNR, unpublished data).

A relatively large proportion of forest on the Clay Belt is old (Harper et al. 2003), with longer fire cycles than other regions of the boreal (Bergeron et al. 2001). Under the current natural disturbance pattern emulation paradigm (OMNR 2001a), this may limit the extent to which EFP may be applied, although the inherent low productivity of the forest is perhaps the most limiting factor. Typical growth rates on the Clay Belt rarely exceed 1 to $2.5 \mathrm{~m}^{3} \cdot \mathrm{ha}^{-1} \cdot \mathrm{yr}^{-1}$ (Whynot and Penner 1990, Groot 2002).

Further to the issue of low productivity, the CMRF is one of 4 Clay Belt forests (along with the Gordon Cosens and Smooth Rock Falls Forests) that have been identified for providing important habitat for forest-dwelling woodland caribou. Increased focus on caribou recovery strategies and pending outcomes of new endangered species legislation may also constrain EFP implementation on this forest, as well as other forests in the Clay Belt.

Given the predominance of wet organic soils, poor accessibility and low productivity, this forest generally has low potential for EFP. Although the Northeast CEC-FRP core team, which covers this forest, provides a close link between forest management planning and research, for the reasons outlined above it is not really suitable as a "core forest" for EFP implementation. However, it is an ideal setting to implement research directed towards biodiversity conservation. It is also important to note that the pending amalgamation with adjacent SFLs may influence the future management direction for the CMRF.

\section{Gordon Cosens Forest}

The Gordon Cosens Forest (GCF) owes its name to a prominent forester and assistant woodlands manager of the forest (1928-1934), who later became dean of the Faculty of Forestry at the University of Toronto (Anon. 1970). The GCF is located primarily on the Clay Belt of the boreal forest region (Rowe 1972, Armson 2001) in northeastern Ontario, around the town of Kapuskasing. The GCF covers approximately $2 \mathrm{M}$ ha, with almost $8 \%$ protected in parks (Fig. 2), and includes approximately $1.5 \mathrm{M}$ ha of Crown productive forest (Table 1). It has been managed as one unit (under Spruce Falls, Inc.) more or less since the 1920s. As well, about 75000 ha of private freehold land managed under the provincial Managed Forest Tax Incentive Program is located within the GCF. Under the authority of Spruce Falls, Inc. SFL, Tembec (Kapuskasing) has been responsible for forest management on the unit since 1997. The northeast CEC-FRP core team is actively involved with the forest management planning team on the GCF, providing a link to the wealth of past and present research in the area. Tembec achieved Forest Stewardship Council (FSC) certification for the GCF in 2003 and was recertified in 2008. The 75000 ha of private freehold land is also included in this certification.

Much of the forest consists of poorly drained organic and gleyed soils (Baldwin et al. 2000), typical of the Clay Belt. However, the southern sections of the GCF include sand plains and gravel ridges, and rich mixedwood site types. The predominant tree species on the GCF is black spruce, however, other distinct forest types and associations occur sporadically. 

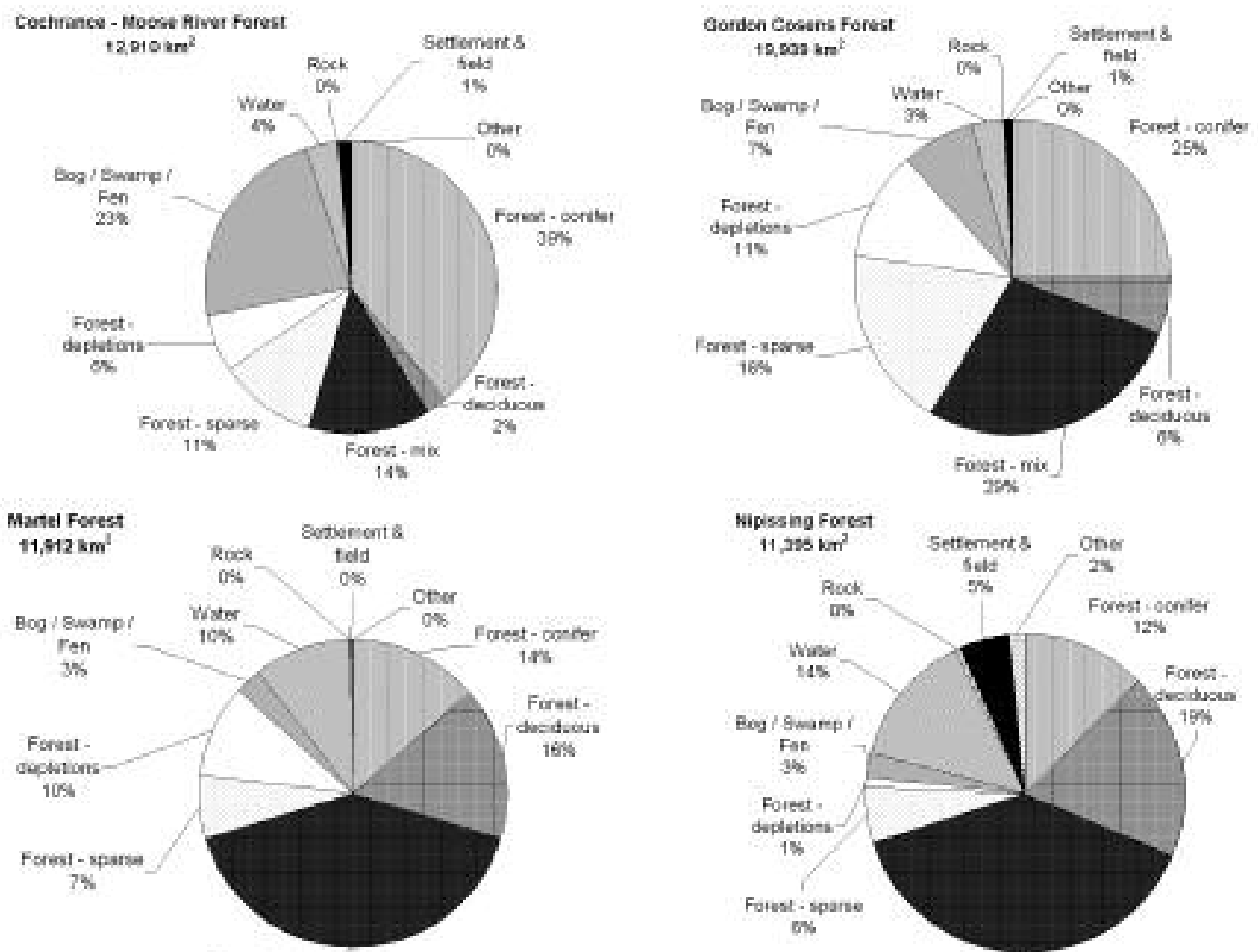

Forst - max

403
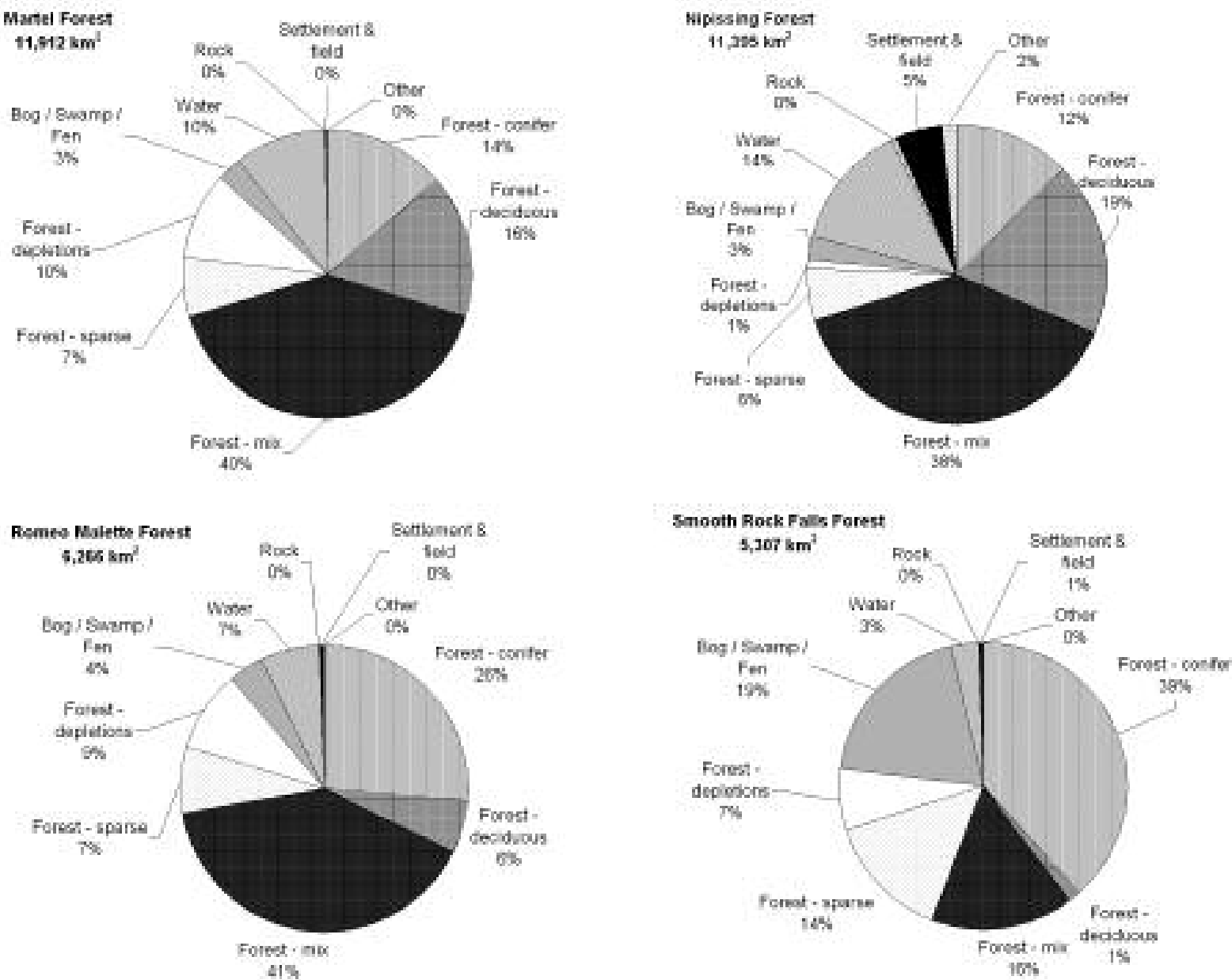

Fig. 3. Proportion of forest management unit area in various land cover classes, based on remotely sensed data (Spectranalysis Inc. 2004). ${ }^{6}$

${ }^{6}$ Discrepancies exist between forest cover classes from satellite (Fig. 3) vs. inventory data (Table 1) due to different class definitions and interpretation. As well, most forest inventories are dated (over 20 years old). 
Table 1. Crown productive forest area (in hectares) by provincial forest type for partnership forests (data from OMNR 2006)

\begin{tabular}{|c|c|c|c|c|c|c|c|c|c|}
\hline & $\begin{array}{l}\text { White } \\
\text { birch }\end{array}$ & $\begin{array}{l}\text { Conifer } \\
\text { lowland }\end{array}$ & $\begin{array}{c}\text { Conifer } \\
\text { upland }\end{array}$ & $\begin{array}{r}\text { Mixed- } \\
\text { wood }\end{array}$ & Jack pine & Poplar & $\begin{array}{l}\text { White and } \\
\text { red pine }\end{array}$ & $\begin{array}{r}\text { Tolerant } \\
\text { hardwood }\end{array}$ & Total \\
\hline Cochrane-Moose R. (ha) & 913 & 574924 & 72495 & 27075 & 13075 & 33538 & - & 30 & 722050 \\
\hline Percentage of total (\%) & 0 & 80 & 10 & 4 & 2 & 5 & 0 & 0 & 100 \\
\hline Gordon Cosens (ha) & 22498 & 811994 & 279422 & 200719 & 22769 & 151760 & 88 & 18 & 1489269 \\
\hline Percentage of total (\%) & 2 & 55 & 19 & 13 & 2 & 10 & 0 & 0 & 100 \\
\hline Martel (ha) & 115761 & 144958 & 154667 & 253160 & 95297 & 75029 & 5563 & 18012 & 862448 \\
\hline Percentage of total (\%) & 13 & 17 & 18 & 29 & 11 & 9 & 1 & 2 & 100 \\
\hline Nipissing (ha) & 86043 & 19181 & 114978 & 50694 & 11132 & 43132 & 91012 & 133992 & 550163 \\
\hline Percentage of total (\%) & 16 & 3 & 21 & 9 & 2 & 8 & 17 & 24 & 100 \\
\hline Romeo Malette (ha) & 48245 & 163959 & 97826 & 114632 & 31229 & 47069 & 688 & 261 & 503909 \\
\hline Percentage of total (\%) & 10 & 33 & 19 & 23 & 6 & 9 & 0 & 0 & 100 \\
\hline Smooth Rock (ha) & 1177 & 272865 & 52254 & 27924 & 553 & 9337 & - & - & 364110 \\
\hline Percentage of total (\%) & 0 & 75 & 14 & 8 & 0 & 3 & 0 & 0 & 100 \\
\hline
\end{tabular}

Large, relatively pure stands of black spruce cover the poorly drained lowlands as well as gently rising uplands. Forest inventory data indicate a predominance of wet, lowland conifer (Table 1). The management unit also includes approximately $1500 \mathrm{~km}^{2}$ of bog/swamp/fen and $3670 \mathrm{~km}^{2}$ of sparse forest (Fig. 3) due to poor drainage on large areas of the unit.

The pre-industrial forest composition for the GCF was reconstructed from Ontario Crown land survey notes for the period 1889 to 1925 (Pinto et al. 2008). This analysis indicates balsam fir, cedar, poplar and spruce are now more frequent; while birch and pine (Pinus), are less frequent than in the previous century (F. Pinto, OMNR, unpublished data).

The nature of the climate, geology, and site conditions of the GCF affects harvest operations and forest access. Relationships between site and stand attributes, environmental factors, and forest operations must be addressed in terms of potential affects on the physical environment. Special operational techniques and equipment have been developed to overcome the operational difficulties that are inherent to the GCF and other forests in the Clay Belt. Due to the high potential for harvesting activities to damage the soils on lowland sites, non-conventional equipment, such as skidders with high floatation tires are used, and harvesting occurs in winter when the ground is frozen. Access to lowland areas is also often restricted to winter roads, which presents forest managers with special challenges in implementing silviculture treatments.

During the 4-year period from 2002 to 2005, harvesting occurred 2004 and 2005). primarily in the lowland conifer forests, averaging approximately 5000 ha annually, with a total annual harvest averaging just over 13000 ha (Fig. 4). Close to 3000 ha of upland conifer and mixedwood is harvested per year, and almost 2000 ha of poplar and white birch. In contrast to the predominantly wet lowland sites (mainly to the north) these upland sites provide large areas of more productive forest that are potentially available for EFP.

Currently around 5000 ha of artificial regeneration occurs each year on the GCF, and almost all of the planted black

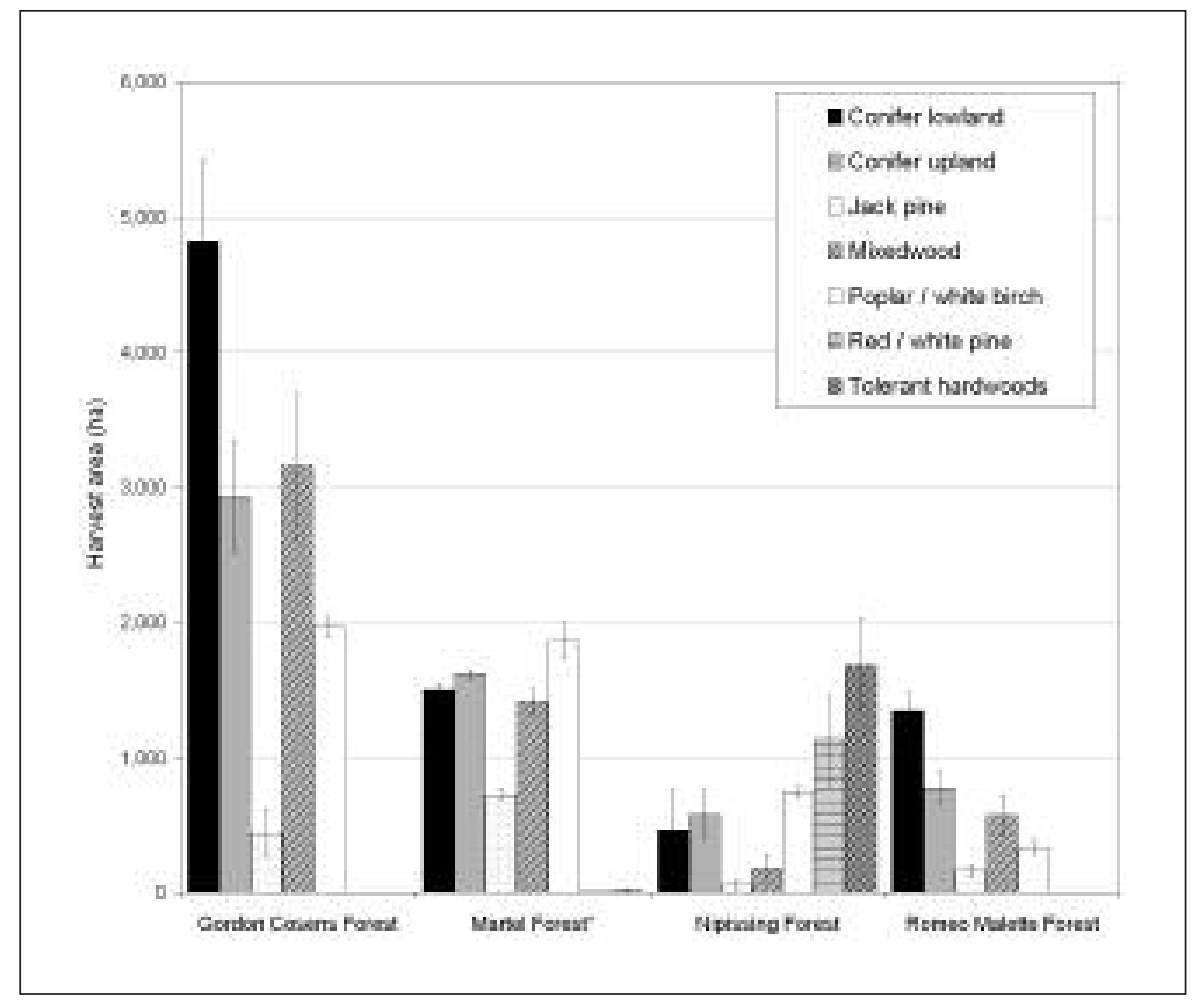

Fig. 4. Average annual harvest area by provincial forest type (poplar and white birch combined) from 2002 to 2005 annual report data (4-year mean \pm standard error) from forest management plans for 4 partnership forests ("Martel Forest data were available only for 
Table 2. Area of silviculture activity (in hectares], summarized from forest management plan annual report data for the partnership forests

\begin{tabular}{|c|c|c|c|c|c|c|}
\hline & & & & & & \\
\hline & Silviculture activity & 2002 & 2003 & 2004 & 2005 & Total \\
\hline Gordon Cosens Forest & Artificial regeneration & 6742 & 6080 & 4897 & 5165 & 22885 \\
\hline & Natural regeneration & 6694 & 5417 & - & 9182 & 21293 \\
\hline & Site preparation & 985 & 689 & 824 & 464 & 2963 \\
\hline & Tending & 5800 & 6767 & 4069 & 7985 & 24621 \\
\hline & Thin (even-aged) & - & 209 & 14 & - & 223 \\
\hline & Thin (uneven-aged) & - & - & 22 & - & 22 \\
\hline Gordon Cosens Forest & & 20221 & 19162 & 9827 & 22796 & 72007 \\
\hline Martel Forest $^{\mathrm{a}}$ & Artificial regeneration & - & - & 3548 & 3589 & 7137 \\
\hline & Natural regeneration & - & - & 2543 & 2532 & 5075 \\
\hline & Site preparation & - & - & 1948 & 2859 & 4808 \\
\hline & Tending & - & - & 4437 & 3759 & 8195 \\
\hline & Thin (even-aged) & - & - & - & 653 & 653 \\
\hline Martel Forest Total & & & & 12476 & 13392 & 25869 \\
\hline Nipissing Forest & Artificial regeneration & 1124 & 1356 & 1481 & 1152 & 5113 \\
\hline & Natural regeneration & 3072 & 5170 & - & 871 & 9113 \\
\hline & Site preparation & 2425 & 338 & 134 & 146 & 3043 \\
\hline & Tending & 649 & 401 & 169 & 426 & 1646 \\
\hline & Thin (even-aged) & 22 & 936 & 432 & 1025 & 2414 \\
\hline & Thin (uneven-aged) & 2579 & 2506 & 138 & 223 & 5447 \\
\hline Nipissing Forest Total & & 9871 & 10707 & 2355 & 3843 & 26777 \\
\hline Romeo Malette Forest & Artificial regeneration & 1424 & 1277 & 1835 & 2303 & 6839 \\
\hline & Natural regeneration & 1226 & 1570 & 1185 & 1464 & 5445 \\
\hline & Site preparation & 1294 & 1031 & 1250 & 1123 & 4698 \\
\hline & Tending & 1348 & 1713 & 2023 & 1548 & 6632 \\
\hline & Thin (even-aged) & 285 & - & - & - & 285 \\
\hline Romeo Malette Forest ' & & 5578 & 5591 & 6292 & 6438 & 23899 \\
\hline
\end{tabular}

${ }^{a}$ Only 2004 and 2005 data are available for the newly amalgamated Martel Forest

spruce is first-generation improved stock. Planting densities are typically 1500 to $2500 \mathrm{stems} \cdot \mathrm{ha}^{-1}$, depending on silvicultural objectives. Tending targets range from 4000 to 5000 ha annually, usually implemented using a single aerial herbicide application. Actual treatment areas for 2002 to 2005 are reported in Table 2. More intensive operations, with higher planting densities and herbicide site preparation plus tending now occur only on a small scale, but a substantial area of wellstocked plantations exist from past renewal efforts, providing opportunities for commercial thinning and shortened rotations. Close to 50000 ha of high-density spruce plantations established in the 1970s and 1980s will soon be suitable for commercial thinning.

An EFP pilot project, which began on the Romeo Malette Forest in 2005, was recently expanded to the GCF (Pitt et al. 2008). Tembec began harvesting a 285 -ha block (F044) close to the Kapuskasing newsprint mill (Spruce Falls, Inc.) in late 2007. Block F044 is an upland site supporting predominantly 70-year-old mixed conifer forest, with evidence of previous harvesting (probably selective). A pre-harvest cruise indicated a total volume of $132 \mathrm{~m}^{3} \cdot \mathrm{ha}^{-1}$, including predominantly black spruce, balsam fir, trembling aspen, white birch (Betula papyrifera Marsh.), balsam poplar (Populus balsamifera L.), and cedar.

The block was harvested with aggregate, rather than dispersed retention of residual trees, with the intent to increase silvicultural effectiveness, wind-firmness, operational productivity, and worker safety. Instead of the guideline-recommended minimum 25 trees ha ${ }^{-1}$, distributed across the block, operators were instructed to leave 100-tree clumps of representative forest for every $200 \times 200 \mathrm{~m}$ (4 ha) of harvest area. Block F044 also includes planned peninsular reserves to satisfy natural disturbance pattern emulation requirements (OMNR 2001a). All harvestable stems of all tree species were removed using full-tree harvesting. Stems were sorted at the stump into merchantable conifer pulp and spruce/pine/fir (SPF) sawlogs, trembling aspen and white birch veneer, and biomass. Following processing and hauling of merchantable wood, a grinder was used to process biomass stems and roadside slash. The biomass operation has several benefits: (1) trucking the ground-up biomass to the mill and burning it supplements the mill's natural gas usage, lowering mill oper- 
ating costs, and reducing fossil fuel gas emissions, (2) high utilization provides a clean site more conducive to effective silviculture, and (3) processing of roadside slash eliminates the need for slash pile burning and makes more areas available for immediate regeneration. The close proximity of the block to the mill site $(<20 \mathrm{~km})$ increases the feasibility of biomass use. FPInnovations-Feric Division is working with Tembec to improve efficiencies and to quantify the amount of useable biomass for future model development (Pitt et al. 2008).

\section{Smooth Rock Falls Forest}

The Smooth Rock Falls Forest (SRFF) is situated around the town of Smooth Rock Falls, Ontario. Until recently, a pulp mill provided considerable local employment and used regional fibre. Managed by Tembec, the SRFF is a small forest relative to others in the province and will likely be amalgamated with adjacent units, including the CMRF. The SRFF received FSC certification in 2005.

The SRFF is in the heart of Clay Belt and has mainly lacustrine and organic soils. As such, it is generally very wet and lowland conifer forest types (mainly black spruce) predominate. Similar to the neighbouring CMRF, it has a large proportion of bog (Fig. 3). These conditions create difficult access, especially given the limited local supply of gravel for road construction and maintenance. Consequently, "winter roads" are often relied upon for access to fibre, which creates an impediment to subsequent silviculture.

The pre-industrial forest composition was reconstructed from Ontario Crown land survey notes for the SRFF for the period 1898 to 1923 using the method described by Pinto et al. (2008). This analysis suggests there are higher frequencies of poplar and spruce and a decrease in larch in the current inventory, as compared to the historic survey records (F. Pinto, OMNR, unpublished data).

The inherent low productivity and difficult access of the SMRF indicate minimal suitability for EFP. Therefore, rather than managing this forest primarily for high-value fibre production, it may be better suited for a management portfolio that relies more on extensive silviculture.

\section{Romeo Malette Forest}

The Romeo Malette Forest (RMF) is situated around the city of Timmins, where Tembec manages the forest from a main office situated at their SPF sawmill site. With one other major SPF sawmill, an oriented strand board (OSB) mill, and a population of over 45000 , Timmins is an important consumer of local wood fibre (aside from the current economic downturn) and is an important economic centre.

Almost 93\% of the total area of the RMF is Crown land, and about $3 \%$ of the area is patent land. These patent lands are mainly mining claims with a mix of timber rights, some being Crown-owned. There is also a small proportion of protected area (just over 2000 ha) or 3.3\% of the forest (Fig 2).

The RMF is entirely within the Boreal Forest Region of Canada (Rowe 1972), and is characterized by extensive coniferous and mixedwood stands on terrain with poorly drained lowlands and gently rising upland areas. The most northern portion of the unit extends into the Clay Belt, which is relatively flat and gently rolling with interspersed eskers and depressions. Conifer lowlands occur primarily here where the water table is high and drainage is poor. The bulk of the man- agement unit is south of the Clay Belt, and consists of welldrained tills, lacustrine and glacial outwash deposits, with some organic deposits between ridges. There is a relatively low proportion of bog, water, and rock (Fig. 3).

Although the RMF consists mainly of boreal forest cover, white (Pinus strobus L.) and red pine (P. resinosa Ait.), red maple (Acer rubrum L.), and yellow birch (Betula alleghaniensis Britt.), which are more typical GLSL forests, are often present in mixed stands on the southern portion of the management unit. Pre-industrial forest composition for the RMF was reconstructed from Ontario Crown land survey notes for the period 1889 to 1930, using the method described in Pinto et al. (2008). This analysis showed total pine and balsam fir occur less frequently now than in the last century, with birch, poplar, maple and spruce occurring more frequently now. Overall, conifer-dominated forest types have decreased over time, with a corresponding increase in intolerant hardwoods (F. Pinto, OMNR, unpublished data).

The RMF received FSC certification in 2004 for the 2002 to 2022 forest management plan. A new forest management plan covering the 2009 to 2029 period is currently being developed with a new inventory, completed in 2005, that includes complete coverage with digital imagery and LiDAR. The new inventory and LiDAR products have provided an important foundation for the ongoing preparation of the forest management plan, operational planning, and spatial analysis with Patchworks. In addition, these inventory products have provided useful tools for EFP implementation by enabling more accurate and efficient planning decisions (Pitt et al. 2008). The renewal of the forest inventory is also crucial to successful adaptive management.

The annual total harvest on the RMF averages just over 3000 ha (Fig. 4). Conifer forest types have dominated the harvest area, although mixedwoods are an increasingly important source of wood supply. The recent distribution of wood supply and demand is shown in Fig. 5. Additionally, the annual wood supply commitments from the 2007 to 2009 contingency forest management plan are $305276 \mathrm{~m}^{3} \mathrm{SPF}$, $3000 \mathrm{~m}^{3}$ of oversize SPF, $700 \mathrm{~m}^{3}$ of pole size SPF, $83700 \mathrm{~m}^{3}$ of poplar OSB, $13380 \mathrm{~m}^{3}$ of poplar veneer, $56400 \mathrm{~m}^{3}$ of birch OSB, and $2500 \mathrm{~m}^{3}$ of birch veneer.

Being a relatively small management unit, annual silviculture treatments average between 1000 and 2000 ha for artificial regeneration, site preparation, and tending (Table 2). Virtually all planted jack pine (Pinus banksiana Lamb.), and black spruce is first-generation improved stock. Commercial thinning has been done on a small scale to date, largely because of cost and expensive monitoring requirements related to its non-recommended status in the boreal silviculture guide (OMNR 1997).

The RMF is the first forest where the CEC-FRP has operationally implemented EFP. An EFP Pilot Project was initiated in 2005 on Block 18 (Pitt et al. 2008), which was selected because of its close proximity $(\approx 25 \mathrm{~km})$ to major processing facilities for OSB and SPF lumber, high site quality, and suitability for conifer production and restoration. Block 18 has a gross area of approximately 526 ha, of which 192 ha and 191 ha were harvested in 2005 and 2006, respectively. A mix of planting and natural regeneration methods were prescribed at $80 \%$ and $10 \%$ of the block area, respectively, with the remaining area in predetermined exclusion zones. Conifer mixes of white (Picea glauca [Moench] Voss) and black spruce, white 

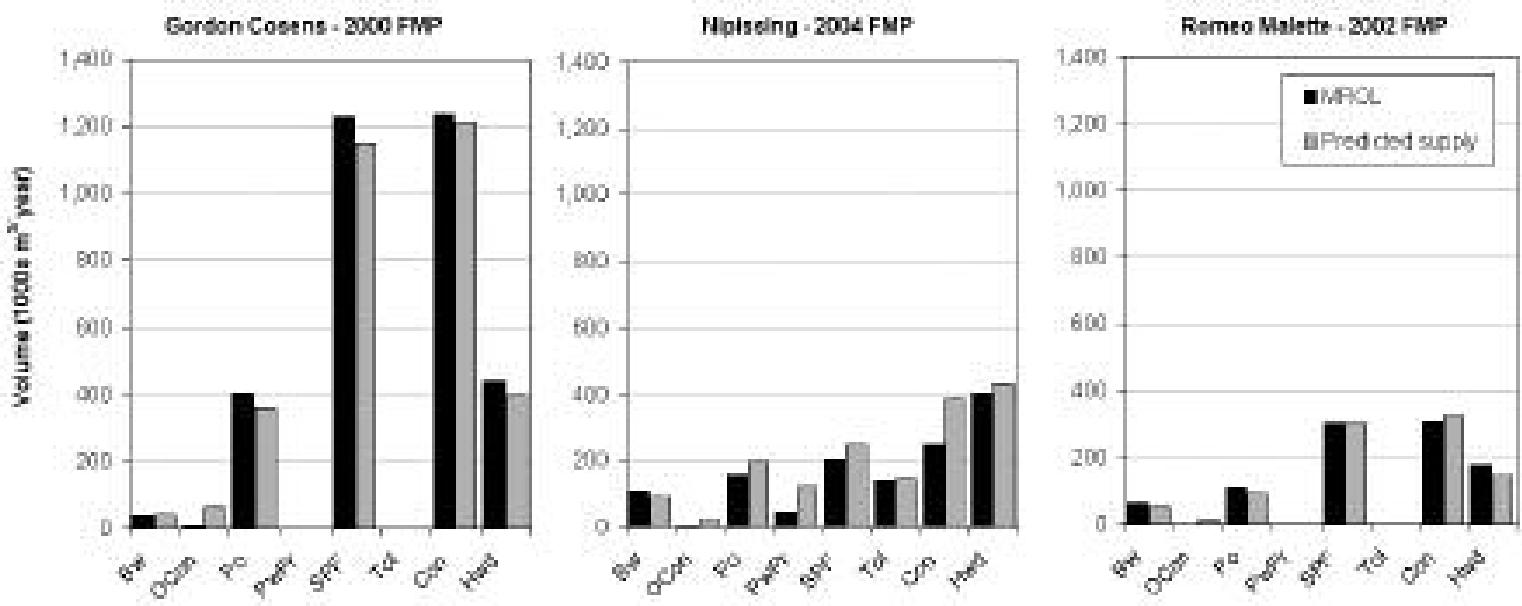

Fig. 5. Industrial demand for wood fibre, based on OMNR recognized operating levels (MROL) and predicted supply from source data for the Provincial Wood Supply Strategy (OMNR 2004b). Data are from the first planning term for each forest management plan (FMP). Bw = white birch; OCon = other conifer; Po = poplar; $\mathrm{PwPr}=$ white and red pine; SPF = spruce, jack pine, balsam fir; Tol = tolerant hardwoods (e.g., maple, beech, oak); Con = total conifer; Hwd = total hardwood.

and red pine, and cedar were planted to achieve at least $90 \%$ stocking at $1.9-\mathrm{m}$ spacing $\left(2800\right.$ seedlings $\left.\mathrm{ha}^{-1}\right)$. On specific microsites, natural regeneration is relied on to maintain hardwood components (aspen and white birch) and unique species, i.e., upland cedar, yellow birch, and black ash (Fraxinus nigra Marsh.). This pilot has provided a tremendous learning opportunity and is anticipated to act as a catalyst to promote further EFP efforts elsewhere on the RMF and in other CEC-FRP affiliated forests.

\section{Martel Forest}

The Martel Forest (MF), surrounding the town of Chapleau, is a recent amalgamation of the Superior and J.E. Martel forests. Managed by Tembec, the MF has a total area of over $1 \mathrm{M}$ ha, of which $84 \%$ is Crown land, 3.3\% is patent land, and 1\% First Nations ownership. Parks and conservation reserves cover over $11 \%$ of the total management unit area (Fig. 2). A unique feature is the height of land separating the Atlantic and Arctic watersheds running through the management unit.

The MF comprises primarily boreal forest. Inventory data for the Crown-owned portion of the unit classifies over 400 000 ha as conifer forest types, just over 190000 ha as intolerant hardwoods (poplar and white birch) and over 250000 ha as mixedwoods (Table 1). Small amounts of tolerant hardwood and white and red pine occur in the southern portion of the unit. Of this, the 2006 to 2026 forest management plan identifies approximately 707100 ha as "managed Crown forest available for timber production." The MF received FSC certification in 2006.

The pre-industrial forest composition for the MF was reconstructed from Ontario Crown land survey notes for the period 1889 to 1923 (Pinto et al. 2008). This analysis showed a significant decrease over time in some conifer forest types, with a corresponding increase in shade-intolerant hardwoods, i.e., balsam fir and pines are less frequent, while birch, cedar, maple, poplar and spruce are more frequent in today's inventory (F. Pinto, OMNR, unpublished data).
The current forest management plan (approved in 2006) highlights the following objectives of providing a consistent supply of roundwood from the forest including: $643000 \mathrm{~m}^{3}$ SPF, $258864 \mathrm{~m}^{3}$ poplar, $150061 \mathrm{~m}^{3}$ white birch, $53523 \mathrm{~m}^{3}$ of cedar and larch, $4700 \mathrm{~m}^{3}$ of white and red pine, and 1033 $\mathrm{m}^{3}$ of tolerant hardwood per year. An important initiative to meet the objective for white birch will be the development of a marketing strategy to use the available volume. As well, there is an objective to commercially thin roughly 200 ha annually.

Annual average harvest area on the MF is approximately 7000 ha, with a relatively even mix of forest types (Fig 3). Artificial regeneration occurs on about 3500 ha per year (Table 2). Generally, soils are productive and provide good potential for EFP.

The MF has only recently become closely affiliation with the CEC-FRP, i.e., during the development of the most recent management plan the northeast core team became actively involved. Consequently, there are new opportunities and potential for future EFP initiatives on the MF.

\section{Nipissing Forest}

Established in 1996, the Nipissing Forest (NF) was one of Ontario's first Crown Management Units to form a co-operative style SFL. Communities within the NF include the City of North Bay, the Municipality of West Nipissing, the Municipality of Powassan, and the villages of Mattawa and Verner, with a total population of approximately 86000 residents, many of whom actively use the forest for recreational purposes. About two-thirds of the total area is Crown-owned (Fig. 2) and 7.5\% is protected in parks. The substantial area of private land located within the boundaries of the forest management unit (23\%) also contributes to the overall wood supply. The NF was FSC-certified in 2003.

The NF lies within the GLSL forest region and supports tree species common to the northern and southern parts of the province (Thompson 2000). As such, it has a diverse mix 
of maples, spruce, eastern hemlock (Tsuga canadensis [L.] Carr.), red oak (Quercus rubra L.), black cherry (Prunus serotina Ehrh.), yellow birch, and beech (Fagus grandifolia Ehrh.). Tolerant hardwoods are the dominant forest type, but a significant proportion (almost 17\%) of the Crown forest area is classified as white pine and red pine (Table 1).

Forest management plans are prepared for the Crown land portions by Nipissing Forest Resources Management Inc. (NFRM), the Sustainable Forest Licensee, in co-operation with OMNR's North Bay District, 5 local First Nations and the Nipissing LCC. An active CEC-FRP core team provides a link between research and planning (Smith et al. 2008, this issue).

Tree species richness and net primary productivity are considerably higher in the NF area than the more northerly forests (Thompson 2000). Productivity estimates for white and red pine on common site types of the NF exceed $5.0 \mathrm{~m}^{3} \cdot \mathrm{ha}^{-1} \cdot \mathrm{yr}^{-1}$ (Woods et al. 1998a). Productivity of managed tolerant hardwood forest types ranges from 2.7 to $5.3 \mathrm{~m}^{3} \cdot \mathrm{ha}^{-1} \cdot \mathrm{yr}^{-1}$ of gross total volume (Woods et al. 1998b). Growth and yield plots established on the NF in 2003, in conjunction with CEC-FRP and Forest Ecosystem Science Cooperative Inc. in red pine plantations planted prior to the 1970s are showing excellent growth potential. Yield projections of these plot data using FVS Ontario (Lacerte et al. 2004, 2006) indicate red pine is reaching 5.8 to $9.4 \mathrm{~m}^{3} \cdot \mathrm{ha}^{-1} \cdot \mathrm{yr}^{-1}$. Accordingly, potential for enhancing productivity and yield on this forest is high.

The pre-industrial forest composition was reconstructed for the NF from Ontario Crown land survey notes for the period 1856 to 1934 (Pinto et al. 2008). This analysis shows birch, maple, jack pine, poplar and spruce are more frequent than in the last century, while tamarack is less frequent. Pines in general, and cedar are significantly less dominant, i.e., their relative proportion within forest stands has decreased by almost $50 \%$ (F. Pinto, OMNR, unpublished data). This change in the forest composition is largely due to past harvesting practices and limited silvicultural efforts. Harvesting on this forest has been ongoing for almost 200 years.

Currently, harvesting on the NF occurs largely on the predominant white and red pine and tolerant hardwood forest types, while poplar and white birch, and mixed conifers contribute lower proportions of harvest volumes (Fig. 4). Stands dominated by white and red pine are managed using the shelterwood silvicultural system, while the tolerant hardwoods are managed using both the selection and shelterwood systems. The predominance of these partial harvest systems explains the low level of forest depletions (1\%) that are identified by remote sensing, compared to other forests (Fig. 3).

A current trend on the NF is to reduce single-tree selection in tolerant hardwoods, with a corresponding increase in group selection and uniform shelterwood. In part, this is to encourage more of the less common mid-tolerant species (oak, black cherry, yellow birch), and because of low quality of the existing maple stands. Pre-harvest inspections show that the average levels of acceptable growing stock (trees that are expected to maintain or improve in value) are below 9.0 $\mathrm{m}^{3} \cdot \mathrm{ha}^{-1}$. Consequently, shelterwood systems are recommended for many stands with poor growing stock that would otherwise be managed under the selection system. This presents both a challenge and an opportunity for EFP implementation: many of these stands can be rejuvenated to more vigorous, higher-value stems, but at a cost of deferring future harvest with the switch from shorter selection harvest intervals to less frequent shelterwood harvest opportunities. Utilization of small-diameter and poor-quality stems also presents a challenge. However, Tembec and the CEC-FRP core team (described in Smith et al. 2008, this issue) have made considerable progress in implementing this strategy with a successful pilot project on Block 108 in Clarkson and Garrow townships. Tembec and the CEC-FRP are now also redefining the selection and shelterwood forest unit criteria for the forest management plan now under development, which will help move this initiative forward.

Silviculture on the NF consists of a blend of artificial and natural regeneration. Site preparation is largely focused on scarification to improve seedbed conditions for natural white pine regeneration in shelterwoods, although some planting is also done (Table 2). The level of tending and chemical site preparation has been relatively low in recent years, but increases are planned following recommendations from CEC-FRP research that stresses the importance of early vegetation control.

Overall, NFRM is very satisfied with the assistance provided by the CEC-FRP. Improvements have been made to the statistical confidence in yield/product curves used in the modelling and preparation of the 2004 and 2009 forest management plans. The CEC-FRP also provided assistance and scientific rationalization for prescribing hardwood shelterwood in low-quality hardwood stands, which has resulted in a short-term increase in harvested volumes.

In addition to increasing the allowable harvest level, NFRM has also been concerned with improving the health of the forest and the quality of timber harvested. NFRM would rather realize a $10 \%$ increase in the quality of the fibre harvested than the overall amount of fibre available. With the assistance of the CEC-FRP, a major project to thin pole-sized yellow birch stands was undertaken. Dead, dying and diseased trees were removed and yellow birch spaced to optimize growth to provide highly valued veneer and sawlog-quality fibre. The work provided much needed year-round employment to 4 Aboriginal contractors and their employees. NFRM and CEC-FRP are also evaluating the potential of using ground hemlock (Canada yew, Taxus canadensis Marsh.) to reduce competition from other seed-origin hardwood species such as poplar and white birch. Other work conducted by NFRM with the assistance of the CEC-FRP involves the regeneration of red oak using group selection harvesting, and acorn storage and planting. These efforts will not only improve success rates for regenerating red oak, but will also contribute to meeting FSC certification standards to maintain and increase the presence of rarer tree species growing on the forest. In the future, CEC-FRP research will need to focus on improving regeneration success for black cherry, which grows in the NF but is at its northern edge of its natural range. Future EFP initiatives should also focus on the feasibility and effectiveness of thinning dense pockets of white pine that resulted from natural regeneration.

\section{Potential EFP Futures for Partnership Forests}

Of the 6 partnership forests evaluated, 4 have relatively high potential for EFP implementation: the GCF, RMF, MF and NF. Large areas of available productive forest, good road access and proximity to mills, OMNR commitments to forest protection, and strong demands for fibre are important 
advantages common to these forests. There are, however, challenges that must be overcome. Determining where, and at what scale, to implement EFP will be a particularly difficult task for planning teams. Wood utilization during low market periods will also likely continue to pose a difficult challenge. Low utilization impedes silvicultural efforts directed towards establishing fully occupied stands, although, the strengthening pulp market and emerging bio-energy initiatives may help with utilization of allocated wood that would otherwise not be harvested. Higher silviculture costs associated with EFP also present challenges, although these must be balanced with wood supply and demand, and should be regarded as an important "investment in the future" (Hawkins et al. 2006). As such, the extent to which EFP should be applied, and its effectiveness, needs to be determined through an adaptive management process.

As described by Bell et al. (2008a, this issue), adaptive management encourages science and forest management professionals to actively engage in reducing uncertainty. Since its inception in 2000, the CEC-FRP has made substantial gains in filling knowledge gaps through experimentation and monitoring, synthesizing published information, creating a new forest resource inventory, and conducting a number of landscape-level analyses. The next step is to apply this new knowledge to enhance productivity and yields on the forests. Landscape-level analysis will be required to determine the proportion of forest lands that will be managed under each intensity (natural disturbance, extensive, basic, intensive or elite practices, see Bell et al. 2008b, this issue) and whether areas should be zoned single- or multiple-use.

Intensive practices, such as thinning and tree improvement, are already applied to varying extent on many of the partnership's affiliated forest management units, but are considered largely experimental. Hence, the proportion of a forest management unit assigned to each intensity level and the spatial distribution of those intensities will require detailed analysis to determine ecological, social, and economic sustainability.

Depending on objectives, forest managers could use conservative or aggressive fibre-supply portfolios, recognizing that each portfolio has associated risks and benefits. Four possible portfolios/strategic alternatives based on fibre production were described by Bell and Baker (2006), from most to least aggressive based on the intensity of silviculture and the proportion of area to which they are applied. Each has implicit assumptions of input costs and future product value outputs. They are:

High Value Future: This management portfolio would apply intensive practices to the highest percentage of area to produce high-value products such as clear dimensional lumber, poles, and veneers. It assumes that a demand for highvalue products will exist in the future, high input costs will produce profitable wood, and effects on biodiversity and ecosystem function will be publicly acceptable. Depending on soil quality and other factors, areas subject to intensive and elite practices might exceed $25 \%$ to $30 \%$ of the landscape.

Bet Hedging with a Senate Sub-Committee Future: This portfolio was recommended by the Senate Subcommittee on the Boreal Forest in 1999 as a means of maintaining a functional boreal forest and a viable forest industry (SSCBF 1999). This is a bet-hedging policy because it assumes a degree of confidence or certainty that world markets will exist for a range of product values, reducing emphasis on use of intensive practices and a higher percentage of protected areas over the "high value future" policy outlined above. The recommended percentage areas were $20 \%$ protected areas, 60\% extensive and basic management, and 20\% intensive management.

Bet Hedging with an OFAAB Future: A portfolio recommended by Ontario Forest Accord Advisory Board (OFAAB) in 2002 that advocates combinations of practices from extensive to intensive to rehabilitate and maintain forest structure and function of the forest following harvest (OFAAB 2002). This portfolio reduces risk by producing a range of product values and assumes that world markets for products ranging from high to low value could emerge. Recommended percentage areas were $12 \%$ protected, $76 \%$ extensive/basic and $12 \%$ of the "commercial forested landbase" under intensive management.

Conservation Future: A portfolio that is not currently being advocated but that deserves some attention because it relies almost exclusively on extensive practices with basic practices implemented only where necessary to meet regulatory requirements. The major driver is minimizing input costs. A major risk is that demand will exist for low-value (e.g., composites) but not high-value products or that the latter cannot be produced profitably. Another major untested assumption and perhaps unacceptable risk is that this policy may not maintain the long-term composition, structure, and/or function of the forest, e.g., conifer forest types may convert to hardwood-dominated conditions, as has often happened in the past (Pinto et al. 2008). The possible percentages for this portfolio are $12 \%$ protected areas and $88 \%$ extensive management with basic practices applied only where necessary to meet legal obligations for forest renewal.

Divergent approaches to the spatial distribution of various management intensities also require consideration. One option is single use zoning or triad principle of land-use zoning, which has recently received a great deal of attention (Seymour and Hunter 1992, Vincent and Binkley 1993, Kimmins 1994, Binkley 1997, Adamowicz et al. 2003, Montigny and MacLean 2006). The approach recommends allocating forested lands into one of three categories (protected areas, extensive management, or intensive management). The triad approach could have economic merit (Vincent and Binkley 1993, Norfolk and Erdle 2005), as well as social equity and future adaptability benefits (Burton 1995); however, a successful triad program will require that the movement to a particular zoning scheme will improve the sum of timber and non-timber values (Adamowicz et al. 2003). This concept may also include a fourth level of elite management (Messier et al. 2003). Another concept, currently practised in Ontario, is to proceed with the use of two zones (1) parks and protected areas, and (2) forest management areas, whereby the latter are managed using a portfolio that incorporates the full suite of silvicultural intensities (i.e., extensive, basic, intensive, and elite silviculture) as required to meet management objectives and obligations for ecological sustainability (Bell et al. 2006).

Regardless of the approach, considerable doubt remains that intensive practices will have merit except in cases where growing conditions are such that positive returns are generated from initial investments, or where costs are relatively low (Adamowicz et al. 2003). Under these conditions, it is plausible that the optimum area designated as intensive under the 
OFAAB portfolio described above could range from 0 to $12 \%$. Accordingly, no two forests are likely to be managed using the same portfolio or spatial distribution pattern.

Sensitivity analysis is required to determine the optimum combination of intensity portfolios and their spatial distribution for each forest prior to their implementation. Where they are used, and at what scale, is controlled through the forest management planning process, which includes public consultation. Inherent in the long-term management direction is a determination of strategic silvicultural options and the extent that they can be applied on the landscape (OMNR 2004a, p. A-34). As such, an analysis of management intensity and where it may apply (e.g., EWSAs) can be determined within the management planning framework.

The CEC-FRP will need to explore potential EFP scenarios on affiliated forests, which have varying degrees of suitability for EFP, but collectively may be managed under a zoning concept that may include EWSAs. With any of the above portfolios/approaches an effective feedback loop is required. Monitoring and evaluation of potential benefits and impacts are necessary to reduce uncertainties and risks before revising management goals and objectives. Silvicultural effectiveness monitoring (SEM) in particular should, therefore, play a large role at the landscape level. An SEM program is inherent to sustainable forest management, and required in Ontario (OMNR 2001b), but will be increasingly important where silvicultural portfolios emphasize EFP. Without these steps of monitoring, evaluation, and adaptation, forest managers have fewer opportunities to learn about the effects of their management on the forests (Smith et al. 2008, this issue).

\section{Summary}

Currently in Ontario there is potential to embrace and implement the concepts of EFP and adaptive management on a broad scale. The CEC-FRP is in the process of applying an adaptive management approach to implement EFP on a portion of the managed forest landbase in northeastern Ontario. Initial efforts were directed, in part, towards identifying forest areas that are conducive to meeting the CEC-FRP's 10/10 objective.

Between the 4 most suitable management units, a vast area of productive forest is available and potentially suitable for EFP, possibly through the designation of EWSAs as stipulated in the Ontario Forest Accord. The size and diversity of the forest landscape allow the integration of EFP while at the same time meeting other forest objectives and obligations for ecological sustainability. The gradient of increasing productivity from north to south allows for a mosaic of protected areas and extensively and intensively managed areas within each forest. The most northerly forests, however, appear better suited to management portfolios emphasizing more extensive management, with intensive management focused on only a few targeted prime sites. The more productive forests to the south, which are also more accessible, have greater potential for higher proportions of the landbase allocated for EFP through the application of more intensive management. In this context, we feel potential is high to realize gains in fibre production and quality while maintaining the ecological integrity and biodiversity in these forests. The application of science-based EFP has the potential to move this landbase towards making the CEC-FRP's $10 / 10$ objective a reality.

\section{Acknowledgements}

Many thanks to Don Higgs and Larry Watkins of OMNR's Forest Evaluation and Standards Section for providing FMP annual report and FRO data, and to Rick Recoskie of OMNR's Northeast Science and Information Section for assistance with satellite data. Reviews of a previous version of this paper by Lisa Buse and two anonymous reviewers are greatly appreciated. Thanks also to Mac Kilgour, OMNR Timmins District, Tom MacLean of Nipissing Forest Resource Management, Inc., Jim Baker of the Ontario Forest Research Institute, Tom Moore of Spatial Planning Systems, and Sue Pickering of Tembec for helpful suggestions on an earlier draft.

\section{References}

Adamowicz, W.L., G.W. Armstrong and M.J. Messmer. 2003. The economics of boreal forest management. In P.J. Burton, C. Messier, D.W. Smith and W.L. Adamowicz (eds.). Towards Sustainable Management of the Boreal Forest. pp. 181-211. NRC Research Press, Ottawa, ON.

Anon. 1970. Gordon Gunn Cosens. For. Chron. 46: 72.

Armson, K.A. 2001. Ontario Forests: A Historical Perspective. Fitzhenry and Whiteside, Ltd. Markham, ON. 233 p.

Baldwin, D.J.B., J.R. Desloges and L.E. Band. 2000. Physical geography of Ontario. In A.H. Perera, D.L. Euler and I.D. Thompson (eds.). Ecology of a Managed Terrestrial Landscape: Patterns and Processes of Forest Landscapes in Ontario. pp. 12-29. UBC Press, Vancouver, BC.

Bell, F.W. and J.A. Baker. 2006. Adaptive forest management. Can. Silv. Mag. Nov 2006: 20-23.

Bell, F.W., J.A. Baker, G. Bruemmer, J. Pineau and A. Stinson. 2008a. The Canadian Ecology Centre - Forestry Research Partnership: Implementing a research strategy based on an active adaptive management approach. For. Chron. 84(5): 666-677.

Bell, F.W., J. Parton, N. Stocker, D. Joyce, D. Reid, M. Wester, A. Stinson, G. Kayahara and W.D. Towill. 2008b. Developing a silvicultural framework and definitions for use in forest management planning and practice. For. Chron. 84(5): 678-693.

Bell, F.W., D.G. Pitt and M.C. Wester. 2006. Is intensive forest management a misnomer? An Ontario-based discussion of terminology and an alternative approach. For. Chron. 82: 662-674.

Bergeron, Y., S. Gauthier, V. Kafka, P. Lefort and D. Lesieur. 2001. Natural fire frequency for the eastern Canadian boreal forest: consequences for sustainable forestry. Can. J. For. Res. 31: 384-391.

Binkley, C.S. 1997. Preserving nature through intensive plantation forestry: The case for forestland allocation with illustrations from British Columbia. For. Chron. 73: 553-559.

Bruemmer, G. 2008. The Forestry Research Partnership: Developing the partnership. For. Chron. 84(5): 648-652.

Burton, P.J. 1995. The Mendelian compromise: a vision for equitable land use allocation. Land Use Pol. 12: 63-68.

Carmean, W.H. 2007. Intensive plantation management for goodsite forest lands in northwest Ontario. For. Chron. 83: 41-53.

Euler, D. and E. Epp. 2000. A new foundation for Ontario forest policy for the $21^{\text {st }}$ century. In A.H. Perera, D.L. Euler and I.D. Thompson (eds.). Ecology of a Managed Terrestrial Landscape: Patterns and Processes of Forest Landscapes in Ontario. pp 276-294. UBC Press, Vancouver, BC.

Groot, A. 2002. Is uneven-aged silviculture applicable to peatland black spruce (Picea mariana) in Ontario, Canada? Forestry 75: 437-442.

Harper, K., C. Boudreault, L. DeGrandpré, P. Drapeau, S. Gauthier and Y. Bergeron. 2003. Structure, composition, and diversity of old-growth black spruce boreal forest of the Clay Belt region in Quebec and Ontario. Environ. Rev. 11: S79-S98.

Hawkins, C.B.D., T.W. Steele, and T. Letchford. 2006. The economics of site preparation and the impacts of current forest policy: evidence from central British Columbia. Can. J. For. Res. 36: 482-494. 
Hegan, R.L. and M.K. Luckert. 2000. An economic assessment of using the allowable cut effect for enhanced forest management policies: an Alberta case study. Can. J. For. Res. 30: 1591-1600.

Kimmins, J. 1994. Sustainable development in Canadian forestry in the face of changing paradigms. In Timber supply in Canada: Challenges and Choices. Conf. Proc. held Nov. 16-18, 1994. Kananaskis, AB. pp. 3-18.

Lacerte, V., G.R. Larocque, M. Woods, W.J. Parton and M. Penner. 2004. Testing the Lake States variant of FVS (Forest Vegetation Simulator) for the main forest types of northern Ontario. For. Chron. 80: 495-506.

Lacerte, V., G.R. Larocque, M. Woods, W.J. Parton and M. Penner. 2006. Calibration of the forest vegetation simulator (FVS) model for the main forest species of Ontario, Canada. Ecol. Model. 199: 336-349.

Lautenschlager, R.A. 2000. Can intensive silviculture contribute to sustainable forest management in northern ecosystems? For. Chron. 76: 283-295.

Lavoie, M., D. Paré, N. Fenton, K. Taylor, A. Groot and N. Foster. 2005. Paludification and forest management in the Northern Clay Section: a literature review. Lake Abitibi Model Forest, Cochrane, ON. LAMF Technical Report \# 1. 75pp + appendices.

Luckert, M.K. and D. Haley. 1995. The allowable cut effect (ACE) as a policy instrument in Canadian forestry. Can. J. For. Res. 25: $1821-1829$

MacLean, D.W. and G.H.D. Bedell. 1955. Northern Clay Belt growth and yield survey. Department of Northern Affairs and Nat. Resour., For. Br., For. Res. Div., Ottawa, ON. Tech. Note No. 20. 31 p. Martell, D.L. and H. Sun. 2008. The impact of fire suppression, vegetation, and weather on the area burned by lightning-caused forest fires in Ontario. Can. J. For. Res. 38: 1547-1563.

Mathey, A.-H., E. Krcmar, J. Innes and I. Vertinsky. 2008. Opportunities and costs of intensification and clustering of forest management activities. Can. J. For. Res. 38. 711-720.

Messier, C., B. Bigué and L. Bernier. 2003. Using fast-growing plantations to promote forest ecosystem protection in Canada. Unasylva. 54: 59-63.

Montigny, M.K. and D.A. MacLean. 2006. Triad forest management: scenario analysis of effects of forest zoning on timber and non-timber values in northwestern New Brunswick, Canada. For. Chron. 82: 496-511.

Norfolk, C.J. and Erdle, T.A. 2005. Selecting intensive timber management zones as part of a forest land allocation strategy. For. Chron. 81: 245-255.

[OFAAB] Ontario Forest Accord Advisory Board. 2001. State of the Ontario Forest Accord. Ont. Min. Nat. Resour., Sault Ste. Marie, ON. Int. Rep. 15 p.

2002. Room to grow: Final report of the Ontario Forest Accord Advisory Board on implementation of the Accord. Ont. Min. Nat. Resour., Sault Ste. Marie, ON. Final Rep. 28 p.

[OMNR] Ontario Ministry of Natural Resources. 1997. Silvicultural guide to managing for black spruce, jack pine, and aspen on boreal forest ecosites in Ontario. Version 1.1. Ont. Min. Nat. Resour., Toronto, ON. 3 books. 822 p.

. 2001a. Forest management guide for natural disturbance pattern emulation. Version 3.1. Ont. Min. Nat. Resour., Toronto, ON. 40 p. 2001b. Silvicultural effectiveness monitoring manual for

Ontario. Ont. Min. Nat. Resour., Toronto, ON. 42 p. 2004a. Forest management planning manual for Ontario's Crown forests - June 2004. Ont. Min. Nat. Resour., Toronto, ON. 440 p. 2004b. Provincial wood supply strategy. Ont. Min. Nat. Resour., Toronto, ON. 92 p.

2004c. Forest fire management strategy for Ontario. Ont.

Min. Nat. Resour., Toronto, ON. 64 p.
2006. Forest resources of Ontario 2006: Appendix in State of the Forest Report 2006. Ont. Min. Nat. Resour., Toronto, ON. 159 p. Park, A. and E.R. Wilson. 2007. Beautiful plantations: can intensive silviculture help Canada to fulfill ecological and timber production objectives? For. Chron. 83: 825-839.

Pinto, F., S. Romaniuk and M. Ferguson. 2008. Changes to preindustrial forest tree composition in central and northeastern Ontario, Canada. Can. J. For. Res. 38: 1842-1854.

Pitt, D., M. Hoepting, D. Thompson, L. Venier, J. Leach, L. Morandin, M. Hall, R. Isaac, S. Pickering, S. McPherson, M. Kilgour, S. Millson, M. Joron, J. Morris, A. Stinson and C. Yurich. 2008. Implementation of enhanced forest productivity: A pilot project on the Romeo Malette Forest. Partners Report - 2007 Field Season (FRP Project 6251). 38 Available at http://www.forest research.ca/Projects/spatial/EFPRMFPartnerReport2007.pdf

Rouillard, D. and T. Moore. 2008. Patching together the future of forest modelling: Implementation of Patchworks in the 2009 Romeo Malette Forest Management Plan. For. Chron. 84(5): 718-730.

Rowe, J.S. 1972. Forest regions of Canada. Can. For. Serv., Ottawa, ON. Publ. No. 1300. 172 p.

Sedjo, R.A. 2001. The role of forest plantations in the world's future timber supply. For. Chron. 77: 221-225.

Seymour, R.S. and M.L. Hunter, Jr. 1992. New forestry in eastern spruce-fir forests: principles and applications to Maine. Maine Agric. Exp. Sta., Univ. Maine, Misc. Publ. 716.

Smith, G.K.M., J.F. Pineau and F.W. Bell. 2008. Knowledge transfer and extension in the Canadian Ecology Centre - Forestry Research Partnership: From awareness to uptake. For. Chron. 84(5): 748-755.

Spectranalysis Inc. 2004. Introduction to the Ontario Land Cover Data Base, $2^{\text {nd }}$ ed.: Outline of production methodology and description of 27 land cover classes. Ont. Min. Nat. Resour., Unpub. Rep.

Standing Senate Committee on Agriculture and Forestry (SSCBF). 1999. Competing realities: the boreal forest at risk. Report of the Sub-Committee on Boreal Forest of the Standing Senate Committee on Agriculture and Forestry. Parliament of Canada, Ottawa, ON. Available at

http://www.parl.gc.ca/36/1/parlbus/commbus/senate/Com-e/boree/rep-e/rep09jun99-e.htm [Accessed 10 Feb. 2008]

Thompson, I.D. 2000. Forest vegetation of Ontario: Factors influencing landscape change. In A.H. Perera, D.L. Euler and I.D. Thompson (eds.). Ecology of a Managed Terrestrial Landscape: Patterns and Processes of Forest Landscapes in Ontario. pp. 30-53. UBC Press, Vancouver, BC.

Vincent, J.R. and C.S. Binkley. 1993. Efficient multiple-use forestry may require land-use specialization. Land Econ. 69: 370-376.

Wagner, R.G. 2005. Forest regeneration trends: Dinosaurs, political correctness and the future. In S.J. Colombo (comp.). The Thin Green Line: A Symposium on the State-of-the-Art in Reforestation: Proceedings. pp. 37-43. Ont. Min. Nat. Resour., Ont. For. Res. Inst., Sault Ste. Marie, ON. For. Res. Inf. Pap. No.160.

Woods, M., J. Rice and E. Boysen. 1998a. Stand growth and yield. Chap. 5.0 In. A Silvicultural Guide for the Great Lakes-St. Lawrence Conifer Forest in Ontario. Ont. Min. Nat. Resour., Toronto, ON.

Woods, M., J. Rice and E. Boysen. 1998b. Stand growth and yield. Chap.7.0 In A Silvicultural Guide for the Tolerant Hardwood Forest in Ontario. Ont. Min. Nat. Resour., Toronto, ON.

Whynot, T.W. and M. Penner. 1990. Growth and yield of black spruce ecosystems in the Ontario Clay Belt: Implications for forest management. For. Can.. Petawawa Nat. For. Inst., Chalk River, ON. Inf. Rep. PI-X-99. 81 p. 